\title{
PEMETAAN BIDANG ILMU PADA SKRIPSI FAKULTAS KEHUTANAN IPB LULUSAN TAHUN 2014-2018 BERDASARKAN STANDAR UNIVERSAL DECIMAL CLASSIFICATION
}

\author{
Oleh: \\ Ir. Rita Komalasari, Azizah, S.Sos
}

\begin{abstract}
ABSTRAK
Fungsi penting hutan tidak bisa kita lupakan. Hutan merupakan penyerap emisi gas rumah kaca dan hutan sebagai sumber ekonomi jika dikelola secara bestari. Pepohonan alami menyerap dan menyimpan karbon dalam tanah. Pada 2015 jumlah karbon yang diserap oleh hutan mencapai 296 Gigaton (Gt). Hutan juga merupakan sumber produk non-kayu dan kayu jika dan hanya jika hutan dikelola secara berkelanjutan. Hutan alami adalah sumber keanekaragaman hayati yang penting bagi ilmu pengetahuan dan memiliki potensi ekowisata yang luar biasa. Kekayaan alam berupa hutan di Indonesia bila dilihat dari luasnya merupakan anugrah yang sangat berlimpah. Hutan dan kehutanan menjadi bagian yang sangat penting dalam keberlangsungan hidup manusia dan makhluk hidup yang ada disekitarnya. IPB University merupakan salah satu perguruan tinggi terkemuka yang memiliki fakultas kehutanan. Tentu dari fakultas ini bermunculan hasil-hasil penelitian baik yang dilakukan oleh mahasiswa maupun dosen. Sayangnya karena belum ada pemetaan hasil penelitian sehingga berpotensi terjadinya topik-topik penelitian yang tumpang tindih atau berulang. Penelitian ini dilakukan dengan tujuan untuk membuat pemetaan bidang ilmu skripsi mahasiswa Fakultas Kehutanan Institut Pertanian Bogor menggunakan standar Universal Decimal Classification dan The Oxford System of Decimal Classification for Forestry. Metode yang digunakan dalam penelitian ini adalah metode deskriptif kuantitatif. Sampel yang digunakan adalah skripsi mahasiswa Fakultas Kehutanan IPB lulusan 2014-2018. Penelitian mahasiswa (skripsi) yang diolah, dikelompokkan berdasarkan subyek besar sesuai dengan departemen, subyek kelas dan bidang Ilmu di Fakultas Kehutanan . Dalam kajian ini juga dibahas mengenai produktivitas kelulusan sarjana berdasarkan departemen per tahun dan produktivitas dosen dalam membimbing mahasiswa dalam kurun waktu 2014-2018. Kajian ini juga menampilkan Sepuluh besar topik penelitian yang paling banyak dan paling sedikit dilakukan berdasarkan bidang ilmu di Fakultas Kehutanan kurun waktu 2014-2018. Hasil penelitian diharapkan mampu menjadi pijakan untuk penelitian-penelitian selanjutnya, baik yang bersifat penelitian pengembangan/lanjutan, maupun penelitian baru yang berbeda dengan penelitian yang sudah dilakukan sebelumnya.
\end{abstract}

Kata kunci: Pemetaan bidang ilmu, skripsi, Fakultas Kehutanan, penelitian lanjutan 


\begin{abstract}
We cannot forget the important function of forests. Forests are an absorber of greenhouse gas emissions and forests are an economic source if managed properly. Natural trees absorb and store carbon in the soil. In 2015, the amount of carbon absorbed by forests reached 296 Gigatons $(\mathrm{Gt})$. Forests are also a source of non-timber and timber products if and only if they are managed sustainably. Natural forests are a source of biological diversity which is important to science and has tremendous ecotourism potential. The natural wealth in the form of forests in Indonesia when viewed from its size is a very abundant gift. Forests and forestry are very important parts of the survival of humans and living things around them. IPB University is one of the leading universities with a forestry faculty. Of course, from this faculty, research results both conducted by students and lecturers emerge. Unfortunately, because there is no mapping of research results, there is the potential for overlapping or recurring research topics. This research was conducted with the aim of mapping the thesis field of students of the Faculty of Forestry, Bogor Agricultural University using the Universal Decimal Classification standard and The Oxford System of Decimal Classification for Forestry. The method used in this research is quantitative descriptive method. The sample used is the thesis of students of the Faculty of Forestry IPB 20142018 graduates. Processed student research (thesis) is grouped based on major subjects according to the department, class subject and field of science at the Faculty of Forestry. This study also discusses the productivity of graduate graduates by department per year and the productivity of lecturers in guiding students in the 20142018 period. This study also featured the top ten research topics that were the most and least conducted based on the field of science at the Faculty of Forestry during the period 2014-2018. The results of the research are expected to be able to become a basis for further research, both developmental / advanced research, as well as new research that is different from previous research.

Key words: mapping scientific research, undergraduate thesis student, Faculty of Forestry, further researches
\end{abstract}

\section{PENDAHULUAN}

Fungsi penting hutan tidak bisa kita lupakan. Hutan merupakan penyerap emisi gas rumah kaca dan hutan sebagai sumber ekonomi jika dikelola secara bestari. Pepohonan alami menyerap dan menyimpan karbon dalam tanah. Pada 2015 jumlah karbon yang diserap oleh hutan mencapai 296 Gigaton (Gt). Hutan juga merupakan sumber produk non-kayu dan kayu jika dan hanya jika hutan dikelola secara berkelanjutan. Hutan alam jauh lebih tinggi nilainya dibanding hutan monokultur. Hutan alami adalah sumber keanekaragaman hayati yang penting bagi ilmu pengetahuan dan memiliki potensi ekowisata yang luar biasa. Mari terus beraksi selamatkan hutan Indonesia. Oleh karena itu kekayaan alam berupa hutan di
Indonesia bila dilihat dari luasnya merupakan anugerah yang sangat berlimpah. Luas hutan Indonesia berada di peringkat 9 dunia di bawah Australia dan Argentina dengan luasan $884.950 \mathrm{~km}^{2}$ atau seluas 88.495.000 Ha (Wikipedia, 2012). Namun sayang sekali Indonesia justru merupakan negara nomor 3 yang kehilangan hutan di antara 10 negara tropis di tahun 2019 yaitu dengan kehilangan seluas $324.000 \mathrm{Ha}$ (Databoks, 2019).

Hutan dan kehutanan menjadi bagian penting dalam keberlangsungan hidup manusia dan makhluk hidup yang ada di sekitarnya. Beberapa manfaat hutan bagi keberlangsungan hidup manusia dan lingkungan antara lain adalah:

(1) berperan sebagai paru-paru dunia, 
menjaga dan mempertahankan kesuburan tanah, sebagai sarana tempat tinggal makhluk hidup, menjadi sumber keanekaragaman hayati, dan mencegah terjadinya bencana alam.

Kekayaan alam berupa hutan di Indonesia bila dilihat dari luasnya merupakan anugerah yang sangat berlimpah. Hutan dan kehutanan menjadi bagian penting dalam keberlangsungan hidup manusia dan makhluk hidup yang ada di sekitarnya. Berdasarkan data Direktorat Jenderal Planologi Kehutanan dan Tata Lingkungan (PKTL) KLHK, hasil pemantauan hutan Indonesia Tahun 2019, menunjukkan bahwa luas lahan berhutan seluruh daratan Indonesia adalah 94,1 juta ha atau 50,1\% dari total daratan. Separuh luas daratan Indonesia yang merupakan lahan berhutan menuntut adanya pengelolaan yang baik dan seimbang sehingga ekosistem dan kelestarian hutan tetap terjaga.

Definisi hutan dan kehutanan serta jenis-jenis dan hal yang berhubungan dengan keberlangsungan hutan sangat jelas diatur dalam Undangundang Republik Indonesia Nomor 41 Tahun 1999 Tentang Kehutanan. Hutan adalah suatu kesatuan ekosistem berupa hamparan lahan berisi sumber daya alam hayati yang didominasi pepohonan dalam persekutuan alam lingkungannya, yang satu dengan yang lainnya tidak dapat dipindahkan. Lebih lanjut didefinisikan mengenai kehutanan adalah sistem pengurusan yang bersangkut paut dengan hutan, Kawasan hutan dan hasil hutan yang diselenggarakan secara terpadu. Dua definisi tersebut menggambarkan banyak hal yang dapat diturunkan dan menjadi tanggung jawab pihak terkait sehingga daya guna dan hasil guna hutan dapat dirasakan oleh masyarakat sekitar dan Indonesia pada umumnya.
Pengelolaan hutan secara maksimal tidak hanya pada keberlangsungan ekosistem hutannya saja tapi juga sesuatu yang dapat dihasilkan sehingga memberikan kesejahteraan secara maksimal. Bagaimana pengelolaan hutan sehingga memiliki kualitas yang baik dibutuhkan keilmuan tersendiri sehingga pertumbuhan hutan terkontrol dan memberikan hasil yang maksimal. Keberadaan hutan tidak terbatas pada sumber daya hayati yang dapat memberikan hasil produksi. Kawasan hutan juga dapat dijadikan ekowisata yang pastinya memberikan nilai ekonomi lebih terutama bagi warga sekitar bila dikelola dengan baik sehingga menarik untuk dikunjungi. Masih banyak lagi manfaat keberadaan hutan yang dapat digali khususnya di wilayah Indonesia.

Sejalan dengan keberadaan hutan yang sangat penting dalam kelestarian lingkungan maka dibutuhkan pendidikan tinggi yang khusus mendalami bidang tersebut. Keberadaan pendidikan tinggi diharapkan dapat memberikan kontribusi dalam penelitian-penelitian berbagai bidang sehingga seluruh aspek kehutanan dapat ditangani dengan baik. Fakultas Kehutanan Institut Pertanian Bogor diawali dengan pemisahan diri Fakultas Pertanian Universitas Indonesia tahu 1963, diikuti oleh perubahan status dari jurusan kehutanan menjadi Fakultas Kehutanan pada tahun 1965. Sesuai penerapan mayorminor di IPB maka terdapat empat fakultas yang diubah menjadi Departemen Manajemen Hutan (DMNH), Departemen hasil Hutan $(\mathrm{DHH})$, Departemen Konservasi Sumber daya Hutan dan Ekowisata (DKSHE), dan Departemen Silvikultur (DSVK).

Empat departemen di Fakultas Kehutanan diharapkan dapat memberikan kontribusi berupa penelitian awal maupun lanjutan dalam rangka kelestarian hutan 
Indonesia. Penelitian yang telah dikakukan oleh mahasiswa/dosen/peneliti, menjadi kekayaan khasanah ilmu pengetahuan bagi Institut Pertanian Bogor. Sejatinya, penelitian yang telah dilakukan oleh mahasiswa empat Departemen di Fakultas Kehutanan Institut Pertanian Bogor (IPB) amatlah banyak. Setiap mahasiswa diberi kebebasan dalam menentukan objek penelitian sesuai dengan bidang keilmuan masing-masing departemen. Namun, apakah penelitian tersebut dapat menggambarkan pola dan jenis penelitian yang telah dilakukan oleh Fakultas Kehutanan IPB?

Untuk menjawab masalah tersebut, perlu langkah-langkah strategis, yaitu dengan membuat penelitian/kajian tentang peta penelitian yang berkaitan dengan peta penelitian dari karya ilmiah yang telah dihasilkan dari berbagai disiplin ilmu di berbagai Fakultas di IPB. Dalam Penelitian ini akan dikaji pemetaan bidang ilmu dari Fakultas Kehutanan IPB. Dari hasil kajian tersebut, diharapkan nantinya akan terukur pola dan jenis penelitian yang telah dilakukan di Fakultas Kehutanan IPB yang selanjutnya dapat digunakan sebagai pijakan untuk melakukan penelitian yang sifatnya berbeda dengan penelitian yang telah dilakukan ataupun dalam mengembangkan penelitian lanjutan. Pemetaan bidang ilmu skripsi Fakultas Kehutanan IPB diharapkan dapat memberikan dampak positif bagi pengembangan khasanah ilmu pengetahuan di IPB khususnya dan di Indonesia pada umumnya.

\section{METODE PENELITIAN}

Metode yang digunakan dalam penelitian ini adalah metode deskriptif kuantitatif. Populasi yang digunakan adalah skripsi mahasiswa Fakultas Kehutanan IPB tahun 2014-2018 (lima tahun terakhir). Pengelompokan kelas bidang ilmu dalam penelitian ini menggunakan standar Universal Decimal Classification dan The Oxford System of Decimal Classification for Forestry. Populasi dari obyek penelitian ini adalah skripsi lulusan Fakultas Kehutanan 5 tahun terakhir, dari tahun 2014-2018. Data skripsi diperoleh dari basis data skripsi di Perpustakaan IPB. Data kemudian ditabulasi berdasarkan kelompok departemen di Fakultas Kehutanan yang terdiri dari: Departemen Hasil Hutan, Departemen Konservasi Sumber daya Hutan dan Ekowisata, Departemen Manajemen Hutan dan Departemen Silvikultur. Data diolah untuk menentukan subyek klasifikasinya berdasarkan topik penelitian dengan memperhatikan tujuan penelitian dan kata kunci dari penelitian tersebut. Standar yang digunakan adalah Universal Decimal Classification dan The Oxford System of Decimal Classification for Forestry. Tabel yang dihasilkan kemudian dianalisis secara deskriptif.

\section{Hasil dan Pembahasan}

Dalam kajian ini, telah dilakukan identifikasi skripsi fakultas Kehutanan dalam kurun lima tahun terakhir yaitu tahun 2014-2018 sebanyak 1924 judul. Sebaran jumlah penelitian mahasiswa (skripsi) dikelompokkan berdasarkan subyek besar sesuai dengan Departemen yang ada di fakultas Kehutanan IPB yaitu:

1. Hasil Hutan, sebanyak 391 judul (20.32\%);

2. Konservasi Sumber daya Hutan dan Ekowisata, 549 judul (28.54\%);

3. Manajemen Hutan, 557 judul $(28.95 \%)$

4. Silvikultur, 427 judul $(22.19 \%)$ 


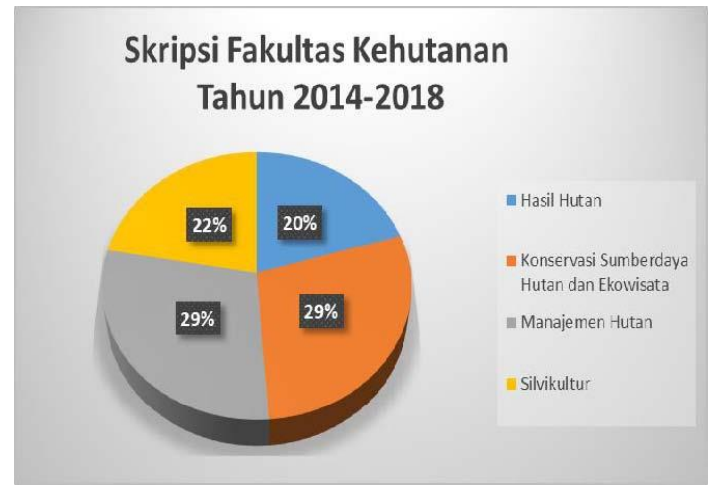

Gambar 1. Sebaran jumlah penelitian skripsi

Fakultas Kehutanan berdasarkan Subyek Besar kurun waktu 2014-2018

Tabel 1 Perincian produktivitas departemen menghasilkan lulusan pada Fakultas

\begin{tabular}{|c|c|c|c|c|c|}
\hline Tahun & HHT & KSH & MNH & SVK & Jml \\
\hline 2014 & 76 & 96 & 113 & 91 & 376 \\
\hline 2015 & 66 & 127 & 122 & 85 & 400 \\
\hline 2016 & 79 & 106 & 104 & 84 & 373 \\
\hline 2017 & 101 & 114 & 108 & 82 & 405 \\
\hline 2018 & 69 & 106 & 110 & 85 & 370 \\
\hline Jumlah & 391 & 549 & 557 & 427 & 1924 \\
\hline
\end{tabular}

Dari Gambar 1. di atas terlihat bahwa jumlah total hasil penelitian skripsi mahasiswa Fakultas Kehutanan IPB selama kurun waktu 2014-2018 yaitu sebanyak 1924 judul penelitian. Penelitian di Departemen Manajemen Hutan (MNH) menempati jumlah tertinggi dengan hasil penelitian sebanyak 557 judul penelitian (28,95\%) Kemudian Departemen Konservasi Sumber daya Hutan dan Ekowisata (KSH) sebanyak 549 judul penelitian (28,54\%), urutan berikutnya adalah Silvikultur (SVK) sebanyak 427 judul penelitian (22,19\%). Pada urutan terakhir adalah Hasil Hutan (HHT) sebanyak 391 judul penelitian $(20.32 \%)$.

Jumlah rata-rata skripsi yang dihasilkan pertahun dalam lima tahun terakhir di Fakultas Kehutanan IPB sebanyak 481 judul yang berasal dari empat departemen. Tahun 2014 skripsi terbanyak dihasilkan oleh Departemen Manajemen Hutan (MNH) yaitu 113 judul. Tahun 2015, 2016, dan 2017 jumlah skripsi terbanyak dihasilkan oleh Departeman Konservasi Sumberdaya Hutan dan Ekowisata (KSH) yaitu 127, 106, dan 114 judul. Tahun 2018 Departemen Manajemen Hutan kembali mencapaian jumlah skripsi tertinggi yaitu 110 judul.

Perincian Produktivitas Kelulusan Berdasarkan Departemen pada mahasiswa Sarjana Strata 1 Fakultas Kehutanan IPB kurun waktu 2014-2018 dapat dilihat pada Gambar 2.

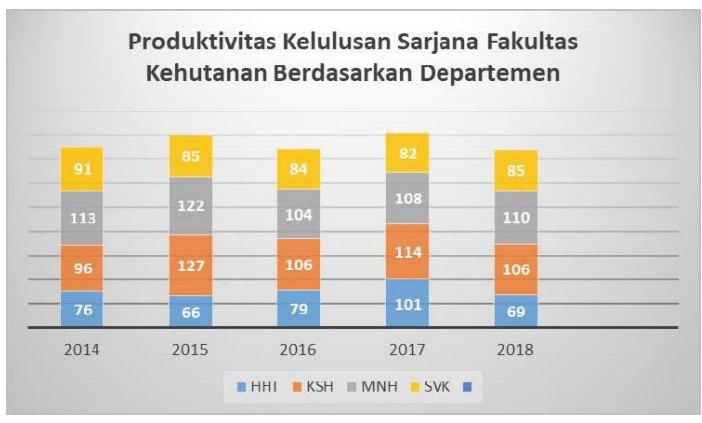

Gambar 2. Produktivitas Kelulusan

Berdasarkan Departemen Sarjana Strata 1 Fakultas Kehutanan IPB kurun waktu 20142018

Keterangan :

HHT $=$ Departemen Hasil Hutan

$\mathrm{KSH}=$ Departemen Konservasi Sumberdaya

Hutan dan Ekowisata

$\mathrm{MNH}=$ Departemen Manajemen Hutan

SVK $=$ Departemen Silvikultur

Dari Gambar 2. terlihat bahwa terdapat ketidakstabilan jumlah penelitian skripsi yang dihasilkan oleh masing-masing Departemen di Fakultas Kehutanan IPB selama kurun waktu 2014-2018. Jumlah terbanyak adalah pada tahun 2017 dengan jumlah penelitian skripsi sebanyak 405 judul yang terdiri dari 114 judul skripsi yang berasal dari Departemen KSH, 108 judul skripsi Departemen MNH, 101 judul skripsi Departemen HHT, dan 82 judul skripsi Departemen SVK. Sedangkan 
jumlah skripsi yang paling sedikit selama kurun waktu 2014-2018 adalah pada tahun 2018 dengan jumlah skripsi sebanyak 370 judul dengan perincian sebanyak 110 judul skripsi Departemen MNH, 106 judul skripsi dari Departemen KSH, 85 judul skripsi dari Departemen SVK, dan yang paling sedikit adalah Departemen HHT yaitu sebanyak 69 judul skripsi.

Gambar 3 di bawah ini menunjukkan sebaran penelitian Subjek Kelas yang digunakan dalam skripsi mahasiswa Fakultas Kehutanan IPB tahun 2014 2018 berdasarkan Universal Decimal Classification (UDC) dan The Oxford System of Decimal Classification for Forestry.

Sebaran penelitian berdasarkan Klasifikasi Subyek Kehutanan

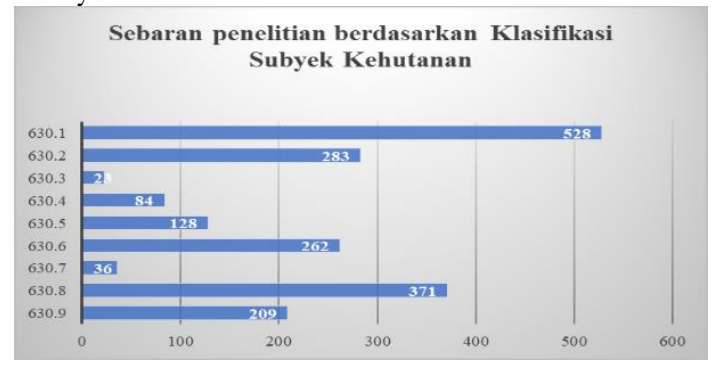

Gambar 3. Sebaran klasifikasi subyek Skripsi Fakultas Kehutanan IPB kurun waktu 20142018 berdasarkan Universal Decimal Classification dan The Oxford System of Decimal Classification for Forestry

Keterangan :

630.1 Faktor faktor yang berkaitan dengan lingkungan, biologi, ekologi, diversifikasi flora dan fauna

630.2 Silvikultur

630.3 Ilmu kerja, pemanenan kayu, penebangan dan transportasi.

630.4 Kerusakan dan perlindungan Hutan

630.5 Pengukuran, Peningkatan, pengembangan dan Struktur tegakan hutan, survey dan pemetaan

630.6 Manajemen hutan, ekonomi bisnis kehutanan, administrasi dan organisasi perngusahaan hutan

630.7 Pemasaran hasil hutan, ekonomi, transportasi hasil hutan dan industri kayu
630.8 Hasil hasil Hutan dan Pemanfaatannya

630.9 Hutan dan kehutanan dari sudut pandang nasional, sosial ekonomi kehutanan

Dari gambar di atas, nampak bahwa penelitian yang berkaitan dengan lingkungan, biologi, ekologi, diversifikasi flora dan fauna mendominasi jumlah penelitian yaitu sebanyak 528 judul penelitan $(27,44 \%)$, sedangkan penelitian di bidang silvikultur sebanyak 283 judul (14,71\%). Penelitian di bidang Ilmu kerja, pemanenan kayu, penebangan dan transportasi sebanyak 23 judul ( $1,20 \%)$, sedangkan ilmu yang berkaitan dengan kerusakan dan perlindungan Hutan sebanyak 84 judul (4.36\%), untuk ilmu yang berkaitan dengan Pengukuran, Peningkatan, pengembangan dan struktur tegakan hutan, survey dan pemetaan sebanyak 128 judul (6.65\%), sedangkan yang berkaitan dengan manajemen hutan, ekonomi bisnis kehutanan, administrasi dan organisasi perngusahaan hutan sebanyak 262 judul $(13.62 \%)$. Penelitian yang berkaitan dengan pemasaran hasil hutan, ekonomi, transportasi hasil hutan dan industri kayu sebanyak 36 judul $(1,87 \%)$, hasil hutan dan Pemanfaatannya sebanyak 371 judul $(19,28 \%)$ dan penelitian yang berkaitan dengan hutan dan kehutanan dari sudut pandang nasional, sosial ekonomi kehutanan sebanyak 209 judul (10.86\%).

Tabel 2. Sepuluh besar topik penelitian yang paling banyak dan sepuluh topik penelitian paling sedikit dilakukan berdasarkan bidang ilmu di Fakultas Kehutanan kurun waktu 20142018

\begin{tabular}{|l|c|c|}
\hline \multicolumn{1}{|c|}{ Bidang IImu } & $\begin{array}{c}\text { Jumlah } \\
\text { judul }\end{array}$ & persentase \\
\hline Regenerasi tumbuhan & 140 & $7,28 \%$ \\
\hline Produk minor kehutanan & 90 & $4,68 \%$ \\
\hline Survey dan Pemetaan & 85 & $4,42 \%$ \\
\hline Lingkungan dan ekonomi Hutan & 83 & $4,31 \%$ \\
\hline Tumbuhan bermanfaat & 81 & $4,21 \%$ \\
\hline $\begin{array}{l}\text { Genetik, pemuliaan dan diversifikasi } \\
\text { fauna }\end{array}$ & 74 & $3,85 \%$ \\
\hline
\end{tabular}




\begin{tabular}{|l|c|c|}
\hline $\begin{array}{l}\text { Hidrologi, konservasi air dan tanah, } \\
\text { DAS }\end{array}$ & 57 & $2,96 \%$ \\
\hline Formasi dan Struktur Tegakan & 56 & $2,91 \%$ \\
\hline $\begin{array}{l}\text { genetik, pemuliaan dan diversifikasi } \\
\text { flora }\end{array}$ & 54 & $2,81 \%$ \\
\hline Kebakaran hutan & 52 & $2,70 \%$ \\
\hline Kontrol dan pengawasan publik & 3 & $0,16 \%$ \\
\hline Articulata & 2 & $0,10 \%$ \\
\hline Manusia dan kerja & 2 & $0,10 \%$ \\
\hline Kondisi yang mempengaruhi kerja & 2 & $0,10 \%$ \\
\hline Kerusakan hutan & 2 & $0,10 \%$ \\
\hline Administrasi kehutanan & 2 & $0,10 \%$ \\
\hline Pengelolaan buruh & 2 & $0,10 \%$ \\
\hline $\begin{array}{l}\text { Perencanaan pembangunan dan } \\
\text { instalasi jalan }\end{array}$ & 2 & $0,10 \%$ \\
\hline $\begin{array}{l}\text { Perencanaan, transportasi, } \\
\text { penyediaan dan perlengkapan }\end{array}$ & 2 & $0,10 \%$ \\
\hline Penyakit virus & 2 & $0,10 \%$ \\
\hline
\end{tabular}

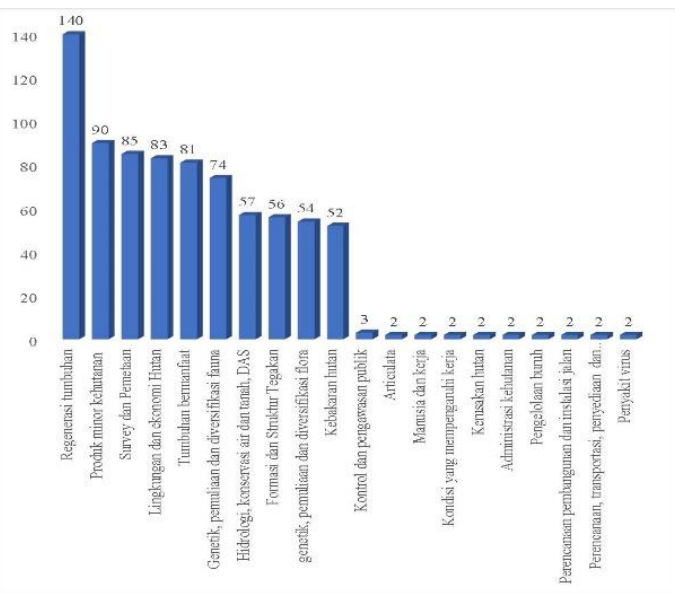

Gambar 4. Sepuluh besar topik penelitian yang paling banyak dan paling sedikit dilakukan berdasarkan bidang ilmu di Fakultas Kehutanan kurun waktu 2014-2018

Dari tabel 2, dan Gambar 4, menunjukkan bahwa Bidang ilmu yang paling banyak diteliti dalam kurun waktu 2014-2018 adalah tentang regenerasi tumbuhan sebanyak 140 topik penelitian ini mencakup formasi tegakan, struktur tegakan, regenerasi alamiah, regenerasi buatan, bibit, pembibitan, pemupukan, perbanyakan vegetatif, metode penanaman, pengaturan penanaman dan permukaan, musim dan waktu penanaman. Sedangkan produk-produk minor kehutanan menduduki rangking ke dua, sebanyak 90 topik penelitian yang mencakup rumput, serasah, produksi pertanian, kulit kayu, produk dari serat kulit kayu, pelet, tumbuhan berkhasiat obat, tumbuhan penghasil insektisida, minyak esensial, bambu, rotan, madu, pati dan karbon. Penelitian terbanyak ke tiga sebanyak 85 judul berkaitan dengan topik survey dan pemetaan, sedangkan Lingkungan dan ekonomi kehutanan sebanyak 83 judul, bidang ilmu terkait tumbuhan bermanfaat sebanyak 81 judul; bidang ilmu terkait genetik, pemuliaan dan diversifikasi fauna sebanyak 74 judul; hidrologi, konservasi air dan tanah, DAS sebanyak 57 judul; topik tentang formasi dan struktur tegakan sebanyak 56 judul; topik tentang genetik, pemuliaan dan diversifikasi flora sebanyak 54 judul dan topik tentang kebakaran hutan sebanyak 52 judul. Topik penelitian yang paling sedikit dilakukan dalam kurun waktu 2014-2018 adalah

Kontrol dan pengawasan publik sebanyak 3 judul, sedangkan topik penelitian tentang articulata; manusia dan kerja; kondisi yang mempengaruhi kerja; kerusakan hutan; administrasi kehutanan pengelolaan buruh; perencanaan pembangunan dan instalasi jalan; Perencanaan, transportasi, penyediaan dan perlengkapan; Penyakit virus masingmasing sebanyak 2 judul .

Produktivitas Dosen Pembimbing Keberhasilan mahasiswa dalam menyelesaikan skripsi tidak terlepas dari peran dosen yang membimbingnya. Produktivitas dosen dalam membimbing dilihat dari banyaknya jumlah mahasiswa yang sudah menyelesaikan skripsinya. 
Tabel 3. Lima Belas (15) Dosen pembimbing paling produktif dalam membimbing skripsi mahasiswa, Fakultas Kehutanan IPB selama kurun

\begin{tabular}{|c|c|c|c|c|}
\hline No & Nama Pembimbing & $\begin{array}{c}\text { Pembimbing } \\
\text { Utama }\end{array}$ & $\begin{array}{c}\text { Pembimbin } \\
\text { g anggota }\end{array}$ & $\begin{array}{c}\text { Jumlah } \\
\text { Bimbingan }\end{array}$ \\
\hline 1. & Hikmat, Agus & 38 & 29 & 67 \\
\hline 2. & Prasetyo, Lilik Budi & 37 & 30 & 67 \\
\hline 3. & Masy'ud, Burhanuddin & 40 & 21 & 61 \\
\hline 4. & Santosa, Yanto & 29 & 14 & 43 \\
\hline 5. & Zuhud, Evrizal AM & 25 & 17 & 42 \\
\hline 6. & Hermawan, Rachmad & 25 & 11 & 36 \\
\hline 7. & Kusrini, Mirza Dikari & 33 & 1 & 34 \\
\hline 8. & Yovi, Efi Yuliati & 30 & 1 & 31 \\
\hline 9. & Muntasib, Endang KSH & 30 & 0 & 30 \\
\hline 10. & Nandika, Dodi & 26 & 2 & 28 \\
\hline 11. & Suwarna, Ujang & 25 & 2 & 27 \\
\hline 12. & Jaya, I Nengah Surati & 26 & 0 & 26 \\
\hline 13. & Santosa, Gunawan & 26 & 0 & 26 \\
\hline 14. & Budiaman, Ahmad & 25 & 0 & 25 \\
\hline 15. & Darmawan, I Wayan & 25 & 0 & 25 \\
\hline
\end{tabular}

Berdasarkan data yang diolah dari basis data Perpustakaan Institut Pertanian Bogor, tentang produktivitas dosen pembimbing, selama kurun waktu 20142018, diperoleh data bahwa dosen yang paling produktif membimbing adalah Dr. Ir. Agus Hikmat, MSc.F dengan jumlah bimbingan sebanyak 67 orang dengan perincian 38 kali menjadi pembimbing utama dan 29 kali menjadi pembimbing anggota. Sedangkan Prof. Dr. Ir. Lilik Budi Prasetyo, MSc., menjadi pembimbing utama sebanyak 37 kali dan pembimbing anggota sebanyak $30 \mathrm{kali}$, dengan total jumlah sama dengan urutan pertama yaitu 67 kali membimbing, disusul oleh Dr. Ir. Burhanudin Masy'ud, MS., dengan 40 kali menjadi pembimbing utama dan 21 kali menjadi pembimbing anggota, dengan jumlah total 61 kali membimbing. Tabel 3. menunjukkan 15 (lima belas) dosen paling produktif membimbing ditinjau dari banyaknya jumlah bimbingan baik sebagai pembimbing utama maupun sebagai pembimbing anggota.

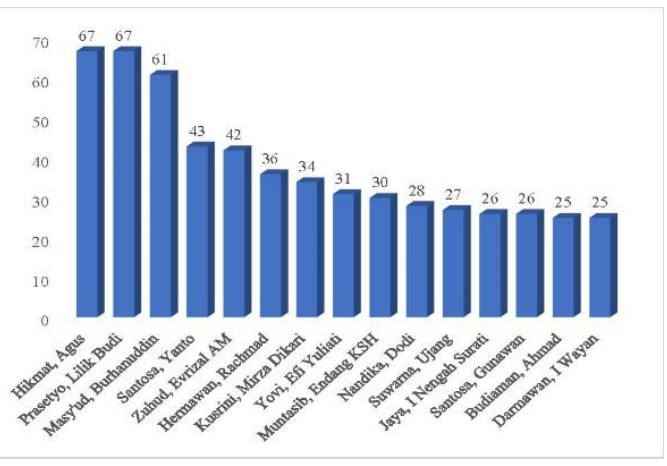

Gambar 5. Lima Belas (15) Dosen pembimbing paling produktif berdasarkan jumlah kumulatif sebagai Pembimbing Utama dan Pembimbing Anggota selama kurun waktu 2014-2018

Keberadaan dosen sebagai pembimbing dikelompokkan menjadi dua yaitu Pembimbing Utama dan Pembimbing Anggota. Berdasarkan jumlah total bimbingan maka Dr. Ir. Agus Hikmat, MSc.F meraih nilai tertinggi dengan jumlah bimbingan sebanyak 67 orang dengan 
perincian 38 kali menjadi pembimbing utama dan 29 kali menjadi pembimbing anggota. Bila dilihat berdasarkan kelompoknya yaitu Pembimbing Utama dan Pembimbing anggota maka diperoleh gambaran sebagai berikut:

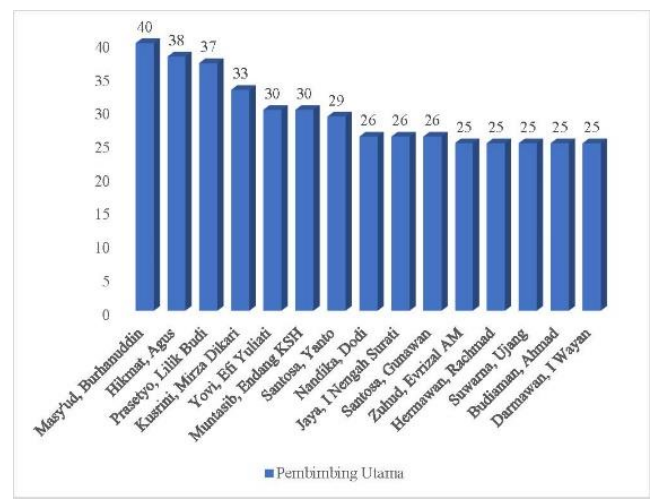

Dosen paling produktif sebagai Pembimbing Utama tahun 2014-2019 adalah Dr. Ir. Burhanudin Masy'ud, MS., membimbing skripsi mahasiswa sebanyak 40 kali bimbingan. Meskipun secara kumulatif yaitu Pembimbing Utama dan Pembimbing Anggota, menjadi urutan ketiga dengan total bimbingan sebanyak 61 skripsi, tapi beliau menjadi urutan pertama dari kelompok Pembimbing Utama. Dari kelompok Pembimbing Anggota, Prof. Dr. Ir. Lilik Budi Prasetyo, MSc. merupakan Pembimbing Anggota paling produktis selama tahun 2014-2019. Jumlah bimbingan selama lima tahun sebanyak 30 bimbingan skripsi mahasiswa. Selain predikat Pembimbing Anggota paling produktif, secara kumulatif beliau ada di urutan kedua sebagai Pembimbing paling produktif dengan capaian jumlah yang sama dengan urutan pertama yaitu sebanyak 67 bimbingan.

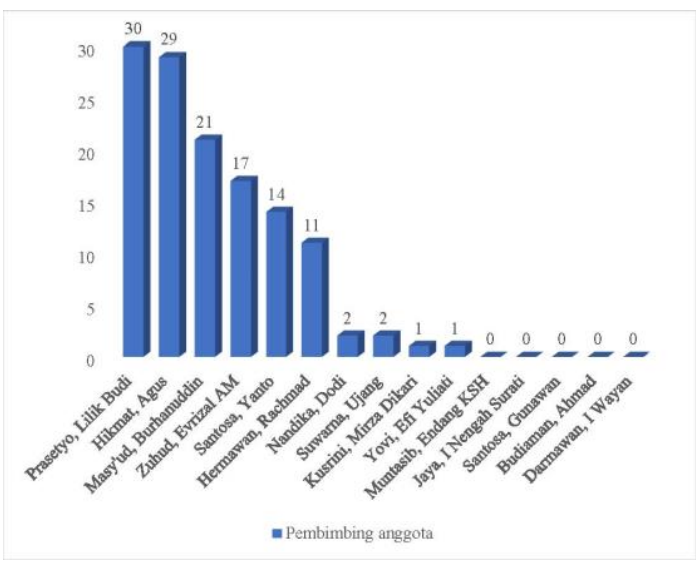

Gambar 7. Nama Dosen sebagai

Pembimbing Anggota Tahun 2014-2019

Kaitan antara produktivitas dosen membimbing dengan peta bidang ilmu menunjukkan hubungan yang positif, di mana dosen yang produktif akan memberikan kontribusi besarnya atau jumlah bidang ilmu yang diteliti oleh mahasiswa. Sebagai contoh adalah Dr. Ir. Agus Hikmat, MSc.F, banyak membimbing mahasiswa dengan topik penelitian tentang regenerasi tumbuhan yang mencakup formasi tegakan, struktur tegakan, regenerasi alamiah, regenerasi buatan, bibit, pembibitan, pemupukan, perbanyakan vegetatif, metode penanaman, pengaturan penanaman dan permukaan, musim dan waktu penanaman. Namun dibutuhkan penelitian lebih lanjut dan lebih mendalam untuk menggali keterkaitan antara produktivitas dosen membimbing dengan pemetaan bidang ilmu di Fakultas Kehutanan IPB.

\section{Kesimpulan dan Saran}

Dari kajian yang telah dilakukan menggunakan sumber kajian dari basis data Perpustakaan IPB, dengan objek kajian Skripsi mahasiswa Fakultas Kehutanan IPB sebanyak 1924 judul dalam kurun waktu 2014-2018, dapat ditarik beberapa kesimpulan sebagai berikut: 
1 Penelitian yang berkaitan dengan lingkungan, biologi, ekologi, diversifikasi flora dan fauna mendominasi jumlah penelitian yaitu sebanyak 528 judul penelitian $(27,44 \%)$; sedangkan penelitian di bidang silvikultur sebanyak 283 judul (14,71\%);

2 Penelitian yang berkaitan dengan pemasaran hasil hutan, ekonomi, transportasi hasil hutan dan industri kayu sebanyak 36 judul $(1,87 \%)$;

3 Bidang ilmu yang paling banyak diteliti dalam kurun waktu 2014-2018 adalah tentang regenerasi tumbuhan sebanyak 140 judul penelitian (7.28\%) yang mencakup formasi tegakan, struktur tegakan, regenerasi alamiah, regenerasi buatan, bibit, pembibitan, pemupukan, perbanyakan vegetatif, metode penanaman, pengaturan penanaman dan permukaan tanam, musim dan waktu penanaman;

4 Bidang ilmu yang paling sedikit diteliti atau baru sedikit diteliti adalah topik penelitian tentang articulata, manusia dan kerja; kondisi yang mempengaruhi kerja, kerusakan hutan, administrasi kehutanan, pengelolaan buruh, perencanaan pembangunan dan instalasi jalan, perencanaan, transportasi, penyediaan dan perlengkapan, serta penyakit yang disebabkan oleh virus.

\section{Saran}

Berdasarkan data yang diperoleh, sebaiknya dilakukan kajian tentang bidang ilmu dari skripsi Fakultas Kehutanan setiap tahun, agar perkembangan ilmu tentang kehutanan dapat diikuti dan dipantau secara lebih spesifik dan terinci, sehingga keputusan atau kebijakan tentang perkembangan ilmu di bidang kehutanan menjadi lebih tepat dan akurat serta fokus sehingga siap menghadapi perubahan zaman dengan tetap berpijak pada kearifan lokal. Perlu dilakukan penelitian lebih lanjut dan lebih mendalam untuk menggali keterkaitan antara produktivitas dosen membimbing dengan pemetaan bidang ilmu di Fakultas Kehutanan IPB.

\section{DAFTAR PUSTAKA}

Fahmawati, Lydia, (2012). "Pemanfaatan Perpustakaan Universitas Indonesia dalam Penyusunan Skripsi”. Jakarta: Universitas Indonesia. Diambil dari http://lontar.ui.ac.id/opac/themes/green/de tail2.jsp?id=20312685\&lokasi

Hetaher, L. Coates, et al. (2018). How We Are Measuring Up? Evaluating Research data Services in Academic Libraries. Journal of Librarianship and Scholarly Communication, Vol 6, general issue (p.3).

Kamus Besar Bahasa Indonesia. Klasifikasi. Diambil dari https://kbbi.web.id/klasifikasi

Kementrian Lingkungan Hidup dan Kehutanan. "Hutan dan Deforestasi Indonesia tahun 2019".

http://ppid.menlhk.go.id/siaran_pers/browse $/ 2435$

Maryati, I., Yoganingrum, A., \& Sihombing, A. (2016). Science mapping as a tool for presentation of information on the information repackaging for the policy make. Konferensi Internasional 2016: Peran Science Mapping dalam Pengembangan Ilmu Pengetahuan di Indonesia (p. 1). 2016: UGM.

Sulistyo-Basuki. (2016). The Role of Bibliometrics and Science Mapping in Science Development. Konferensi Internasional 2016: Peran Science Mapping dalam Pengembangan Ilmu Pengetahuan di Indonesia (p. 6). Yogyakarta: UGM.

The Oxford System of Decimal Classification for Forestry. 1981. Commonwealth Agricultural Bureaux, Helsinki.

Undang Undang No. 41 Tahun 1999 Tentang : Kehutanan. https://jdih.bpk.go.id/wpontent/uploads/2011/03/uu1999_41Kehuta nan.pdf

Universal Decimal Classification. 2008. British Standards Institution, London.

Universal Decimal Classification. Encyclopaedia Britannica. Diambil dari https://www.britannica.com/science/Universal -Decimal-Classification

Yulia, Yuyu \& B. Mustafa (2009). Materi pokok pengolahan bahan pustaka; 1 -9; PUST 2134. Jakarta: Universitas Terbuka 